\title{
BCL-6 Corepressor
}

National Cancer Institute

\section{Source}

National Cancer Institute. BCL-6 Corepressor. NCI Thesaurus. Code C101093.

BCL-6 corepressor (1755 aa, $192 \mathrm{kDa}$ ) is encoded by the human BCOR gene. This protein plays a role in the negative regulation of transcription. 